\title{
DYNASTIC TABLES
}

\section{The Great Khans}

Chinggis

(1206-1227)

Ögedei

(1229-1241)

Güyük

(1246-1248)

Mőngke

(1251-1259)

Qubilai

(1260-1294)

The Il-Khans of Persia

Hülegü

(1256-1265)

Abaqa

(1265-1282)

Tegüder

(1282-1284)

Arghun

(1284-1291)

Geikhatu

(1291-1295)

Baidu

(1295)

Ghazan

(1295-1304)

Öljeitü

(1304-1316)

Abū Sa'īd

(1316-1335)

The Khans of the Ulus of Jochi / Golden Horde

Jochi

(d.1227)

Batu

(1237-1255)

Sartakh

(1256-1257)

Ulaqchi

(d. 1257)

Berke

$(1257-1267)$

Möngke-Temür

$(1267-1280)$

Tőde-Mőngke

$(1280-1287)$

Tőle-Buqa

$(1287-1290)$

Toqta

$(1291-1312)$

Öz-beg

$(1313-1341)$

Tini-beg

Jani-beg

$(1341-1342)$

Berdi-beg

$(1342-1357)$

$(1357-1359)$ 


\section{The Khans Chaghatai Ulus}

Chaghatai

(1227-1242)

Qara- Hülegü

(1242-1246)

Yesü-Mőngke

$(1246-1251)$

Orghina

(1251-1260)

Aluqu

Mubarak-shah

(1260-1265/6)

Baraq

(1266)

Negübei

(1266-1271)

(1271)

Toqa-Temür

(1272-1282)

Duwa

(1282-1307)

Kőnchek

(1308)

Taliqu/Talibuqa

(1308-1309)

Esen-Buqa

Kebek

$(1310-1318)$

(1318-1326)

Elchigidei

Duwa-Temür

(1326-1328)

$(1328-1330)$

Tarmashirin

(1330-1334)

Buzan

Chingshi

(1334)

(1334-1338)

Ali-Sultan

$(1338-1339)$

Yesü-Temür

(1339-1342)

Turalcha-Temür

Ghazan

$(1342-1343)$

(1343-1346)

The Armenian Kings of Cilicia

Het'um I

Lewon III

Het'um II

Lewon IV

Oshin I

Lewon $\mathrm{V}$
(1226-1269, d.1270)

(1269-1289)

(1289-1293; 1295-1297;

1299-1305; joint rule

1305-1307)

$(1305-1307)$

$(1308-1320)$

$(1320-1341)$

The Georgian Kings and Queens

Queen Tamara

$(1184-1213)$

Georgi IV Lasha

(1213-1223) 
Queen Rusudan

David VI Narin

David VII Ulu

Dimitri (Demetrē) II

Vakhtang II

David VIII

Georgi V

Vakhtang III

Georgi VI
(1223-1245)

(1245-1259) (King of Western

Georgia 1259-1293)

(1247-1259) (King of Eastern

Georgia 1259-1270)

(1270-1289)

(1289-1292)

(1293-1311)

(1299-1302; 1314-1346)

(1302-1308)

(1311-1313)

\section{The Mamluk Sultans}

Al-Muẓaffar Quțuz

Al-Zahir Baybars al-Bunduqdārī

Al-Sa īd Berke Khan b. Baybars

Al-Manșūr Qalāwūn b.Alfi

Al-Ashraf Khalīl b. Qalāwūn

Al-Nāṣir Muhammad b. Qalāwūn
$(657 / 1259-658 / 1260)$

$(658 / 1260-676 / 1277)$

$(676 / 1277-678 / 1279)$

$(678 / 1279-689 / 1290)$

$(689 / 1290-693 / 1293)$

(693/1293-694/1294;

698/1299-708/1309;

$709 / 1310-741 / 1340)$ 